\title{
LA JOLLA NATURAL RADIOCARBON MEASUREMENTS VII
}

\author{
T W LINICK
}

Mt Soledad Radiocarbon Laboratory, Department of Chemistry University of California, San Diego, La Jolla, California 92093

INTRODUCTION

Radiocarbon dating of many types of samples has continued at the La Jolla Radiocarbon Laboratory since the last date list was published (Bien and Pandolfi, 1972). Since the 1969 relocation of the laboratory to its present location on Mt Soledad, at least 5 low-level ${ }^{14} \mathrm{C}$ systems have generally been in operation. The laboratory has continued to employ acetylene gas proportional counting. Samples were usually measured for 2 to 3 days in each of 2 different detectors. The properties of the 5 counters used in the measurements of samples are as follows (background and net standard counts per minute, respectively, with acetylene of 900 mmHg pressure are given in parentheses): 1) Bern counter: Oeschgertype counter-guard ring unit with $1.7 \mathrm{~L}$ sensitive center volume $(2.1,21.5)$, 2) MBLE counter: Oeschger-type counter-guard ring unit with $1.6 \mathrm{~L}$ center volume $(1.3,17.4), 3)$ 1L counter with separate $Q$-gas flow guard ring $(4.2,12.9), 4) 0.4 \mathrm{~L}$ counter with separate guard ring $(1.2,4.2)$, and $0.1 \mathrm{~L}$ counter with separate guard ring $(0.7,1.2)$.

Samples were measured relative to $95 \%$ of NBS oxalic acid activity corrected to a $\delta^{13} \mathrm{C}$ of $-19 \%$ (PDB), except for measurements in the Bern and MBLE counters, where 1871 to 1880 Douglas fir wood was usually taken as the standard material, with activities age-corrected to 1950 and isotopic composition-corrected to a $\delta^{13} \mathrm{C}$ of $-25 \%$. The background counting rates of the detectors were determined by measuring acetylene prepared either by processing anthracite coal in the usual fashion or by hydrolysis with tritium-free well water of inactive calcium carbide. All sample results, including those for marine shells, were corrected for isotopic fractionation relative to $\delta^{13} \mathrm{C}=-25 \%$ according to the Lamont normalization (Broecker and Olson, 1959). Dates listed here are conventional Libby dates calculated on the basis of the 5568-year Libby ${ }^{14} \mathrm{C}$ halflife; uncertainties given are one standard deviation errors ( $1 \sigma)$ based only on statistical counting uncertainties in background, standard, and sample activities. For ages of shell samples, the activity of the dissolved carbonate in the seawater which is generally 1 to $8 \%$ below that of the contemporaneous atmosphere (after $\delta^{13} \mathrm{C}$ correction) should be considered (Suess, 1954; Rafter, 1955). To determine true ages for samples with radiocarbon ages of $<7000 \mathrm{yr}$, results must be compared with those from bristlecone pine wood of precisely known tree-ring age (Ferguson, 1968; Suess, 1967).

Samples were treated as follows: charcoal, wood, and peat were first treated with hot $2 \mathrm{~F} \mathrm{HCl}$. If the sample would not disintegrate upon treatment with basic solution, it was next treated with hot dilute $\mathrm{NaOH}$ solution, then retreated with $2 \mathrm{~F} \mathrm{HCl}$. Finally, the sample was rinsed with distilled water and dried in a $110^{\circ} \mathrm{C}$ oven, and was then combusted in oxygen stream. 
Shells and coral were first treated with $0.2 \mathrm{~F} \mathrm{HCl}$ to remove the outer portion, then reacted with $2 \mathrm{~F} \mathrm{HCl}$ in a vacuum system. The inorganic carbon in sediments and the phosporite rock was released as $\mathrm{CO}_{2}$ by reaction with $2 \mathrm{~F} \mathrm{HCl}$. The organic carbon in some sediments and the phosporite rock was also analyzed; after removing the inorganic carbon by acidification, the samples were filtered, dried, and combusted in an oxygen stream.

Marine organisms were generally prepared as follows: muscle of organisms preserved by freezing only was dried, either through baking or vacuum dessication, and combusted.

$\mathrm{CO}_{2}$ produced in the above manners was converted to acetylene by reaction with molten lithium metal to produce $\mathrm{Li}_{2} \mathrm{C}_{2}$, followed, after cooling to room temperature, by hydrolysis with tritium-free well water. The acetylene was purified for counting by passage through traps at dry ice temperature, traps filled with glass balls coated with $\mathrm{P}_{2} \mathrm{O}_{5}$, and traps filled with activated charcoal at $0^{\circ} \mathrm{C}$. Samples were allowed to age for at least 3 weeks to allow any radon present to decay before radiocarbon analysis. After ${ }^{14} \mathrm{C}$ analysis, a small sample of the acetylene was recombusted to $\mathrm{CO}_{2}$ without isotopic fractionation by adding $\mathrm{O}_{2}$ and circulating over cupric oxide at $600{ }^{\circ} \mathrm{C}$. The $\delta^{13} \mathrm{C}$ of the $\mathrm{CO}_{2}$ was then measured mass-spectrometrically.

The date list for samples measured from Feb 1971 to Nov 1975 follows, with samples divided into 3 categories: 1) material from human habitation sites on 4 continents, 2) ocean and lake sediments, plus other materials used to study sedimentation rates, and 3) marine organisms. Several hundred samples of other types, in particular dendrochronologically-dated wood and bicarbonate dissolved in ocean water, were also measured by the La Jolla Lab. Results have been or will be published elsewhere (Cain and Suess, 1976; Linick and Suess, 1972; Linick, ms in preparation).

\section{ACKNOWLEDGMENTS}

Measurements by the La Jolla Radiocarbon Lab were financed by National Science Foundation Grants GA-25952 and DES-74-22864, with H E Suess as Principal Investigator. Samples were prepared by C S Hutto and T L Broadwell. Mass spectrometric $\delta^{13} \mathrm{C}$ measurements for samples with LJ numbers smaller than 2725 were performed by $\mathrm{K}$ Podvin in the lab of $\mathrm{H}$ Craig; those for later samples were made by $\mathrm{W} F$ Cain, $\mathrm{T}$ L Broadwell, and C S Hutto of this lab. D K Sullivan designed, constructed, and has maintained the counting electronic equipment.

\section{IN MEMORIAM}

It is with great sadness that we report the passing in 1975 of George S Bien. From 1958 until his retirement in 1971, Dr. Bien supervised the operation of this lab. He co-authored all previous La Jolla date lists pub in this journal. 


\section{SAMPLE DESCRIPTIONS}

\section{ARCHAEOLOGIC SAMPLES}

\section{Anza series}

\section{A. Europe}

The following samples from Anza, Macedonia, Yugoslavia, are a continuation of the series started in Bien \& Pandolfi (1972). The samples were coll 1969-1970 by an American team led by M Gimbutas. Samples were also subm by M Gimbutas, Univ Calif, Los Angeles.

Anza, a stratified Central Balkan Neolithic habitation site, is adjacent to the modern village of Anzabegovo, midway between towns Štip and Titov Veles, $10 \mathrm{~km} \mathrm{~S}$ of Sveti Nikole, in Ovče Polje basin, E Macedonia, Yugoslavia (ca $41^{\circ} 42^{\prime} \mathrm{N}, 22^{\circ} 00^{\prime} \mathrm{E}$ ). The settlement lies on a low terrace of the Nikolska R, a small tributary of Bregalnica $R$ in the Aegean drainage basin of the middle Vardar R. The greatest stratified depth found at Anza was ca 4.6m, with Neolithic-Chalcolithic deposits, divided into 4 phases (I to IV, from earliest to latest; Ia precedes Ib). In current archaeol terminology, the earlier 3 Anza phases correspond to the Starčevo culture, the latest phase (Anza IV) to the Early Vinča culture. No later prehistoric deposits were found at Anza, and no traces of later Neolithic-Chalcolithic occupation were found anywhere in E Macedonia. The Anza IV deposit was immediately overlain in the center of the site by remains of Roman habitation. See Gimbutas (1972, 1974) for further discussions.

\section{LJ-2178. Anza, VII-87}

$7050 \pm 150$ 5100 вс datum.

Charcoal from Sq VII, Unit $87,65 \mathrm{~cm} \mathrm{E,} 105 \mathrm{~cm} \mathrm{~N}, 291 \mathrm{~cm}$ below

\section{LJ-2185. Anza, V-62}

$6510 \pm 110$

Charcoal from Sq V, Unit $62,28 \mathrm{~cm} \mathrm{E,} 60 \mathrm{~cm} \mathrm{~N}, 355 \mathrm{~cm}$ below datum, from small post-hole, Phase III.

\section{LJ-2329. Anza, XX-190}

$6230 \pm 60$

Charcoal from Sq XX, depth ca $190 \mathrm{~cm}$ below datum, Phase IV.

$$
4280 \text { BC }
$$

\section{LJ-2330/LJ-2331. Anza, VII-257}

$7180 \pm 60$

Charcoal from Sq VII, Unit 257 , depth $437 \mathrm{~cm}$ below datum. From fire-pit of settlement's earliest occupation horizon; expected to be oldest sample from Sq VII, Phase Ia.

\section{LJ-2332. Anza, VII-256}

Charcoal (charred wood) from Sq VII, Unit 256, depth 427 to $437 \mathrm{~cm}$ below datum, Phase Ib. 


\section{LJ-2333. Anza, VII-253}

$6840 \pm 120$

Charcoal (charred wood) from Sq VII, Unit 253, depth 417 to $427 \mathrm{~cm}$ below datum, Phase II.

\section{LJ-2337. Anza, VII-122}

$7080 \pm 60$

Charcoal from Sq VII, Unit 122, from 2nd block layer of fire-pit, Phase Ib or II. Pit starts at Phase III, but cuts through Phase II down to Phase Ib. Sample was expected by M G to be younger than LJ-2351: $7090 \pm 110$, and younger than LJ-2156: $6630 \pm 150(\mathrm{R}, 1972, \mathrm{v} 14, \mathrm{p} 372)$.

\section{LJ-2338. Anza, VII-177}

$6800 \pm 140$

Charcoal from Sq VII, Unit 177, from fire-pit, Phase II.

\section{LJ-2339. Anza, VII-240}

$7110 \pm 70$

Charcoal from Sq VII, Unit 240, depth 397 to $407 \mathrm{~cm}$ below datum; combination of samples coll throughout unit, Phase Ib.

\section{LJ-2341. Anza, VII-188}

$7230 \pm 170$

Charcoal from Sq VII, Unit 188, depth 367 to $377 \mathrm{~cm}$ below datum; same layer as LJ-2339, Phase Ib. LJ-2342 (R, 1972, v 14, p 373) from Sq VII, Unit 251, was from same layer as LJ-2339 and -2341 and gave age: $7120 \pm 100$.

\section{LJ-2343. Anza, VII-121}

$7000 \pm 280$

Charcoal from Sq VII, Unit 121, depth $316 \mathrm{~cm}$ sloping to $374 \mathrm{~cm}$ below datum, end of Phase II/transition to Phase III.

\section{LJ-2344. Anza, VII-117}

$7000 \pm 270$

Charcoal from Sq VII, Unit 117, overlying LJ-2343, Phase III.

\section{LJ-2345. Anza, VII-191}

$6540 \pm 120$

Charcoal from Sq VII, Unit 191, depth ca $350 \mathrm{~cm}$ below datum; sample coll throughout unit. Phase III (lower part of sloping layer of Phase III). Other results for material from Phase III are UCLA-1705B: $6540 \pm 120$ and UCLA-1705C: $6700 \pm 80$ (Ferguson et al, 1976).

\section{LJ-2347. Anza, V-120}

$$
6700 \pm 150
$$

Charcoal from Sq V, Unit 120, depth 370 to $380 \mathrm{~cm}$ below datum. Expected to be Phase Ia, but age is less than expected for Phase Ia. 
LJ-2349. Anza, VII-189

$6440 \pm 120$

$4490 \mathrm{BC}$

Charcoal from Sq VII, Unit 189, depth 367 to $377 \mathrm{~cm}$ below datum; sample coll throughout unit, Phase Ib.

LJ-2351. Anza, VII-124

$7050 \pm 80$

Charcoal from Sq VII, Unit 124; sample coll throughout unit. Stratigraphically, same as LJ-2343, Phase II.

\section{LJ-2405. Anza, VII-213 \& 215}

$6940 \pm 80$

Charcoal from Sq VII, Units 213 \& 215 , depth 387 to $397 \mathrm{~cm}$ below datum; in Unit 215,150 to $170 \mathrm{~cm} \mathrm{~N}, 0$ to $20 \mathrm{~cm} \mathrm{E}$, Phase II.

LJ-2409. Anza, VII-156

$6850 \pm 50$

4900 вс

Charcoal from Sq VII, Unit 156, from ash ring of well-preserved firepit, Phase II. LJ-2156 (R, 1972, v 14, p 372) from same fire-pit, depth $354 \mathrm{~cm}$ below datum, gave age: $6630 \pm 150$.

\section{LJ-2411. Anza, VIII-55}

$6070 \pm 190$

Charcoal from Sq VIII, Unit 55, Phase IV.

4120 BC

\section{LJ-2519. Anza, L-16}

$7560 \pm 70$ 5610 BC

Charcoal from Block L, Level 16, depth 219 to $229 \mathrm{~cm}$ below datum. Sample was oldest of any Anza sample.

\section{LJ-3032. Anza, V-103 to 120}

$7210 \pm 50$

5260 вС

Charcoal from Sq V; Unit 103, 106, 107, 111, and 120; depth 370 to $380 \mathrm{~cm}$ below datum, Phase Ia.

\section{LJ-3183. Anza, V.90 to 110}

$7150 \pm 50$

Charcoal of Juniperus from Sq V, depth 90 to $110 \mathrm{~cm}$ below datum, definitely from 1 layer, Phase Ia.

\section{LJ-3185. Anza, V-125 to 155}

$6830 \pm 70$ $4880 \mathrm{BC}$

Charcoal of Quercus, Juniperus, and several other trees from Sq V, combination of Units 125 to 155 . Expected to be Phase Ia, but age is for Phase III.

\section{LJ-3187. Anza, V-76 to 86, 116 to 124}

$7150 \pm 70$ $5200 \mathrm{BC}$

Charcoal from Sq V, Units 76 to 86 and 116 to 124, depth 390 to $410 \mathrm{~cm}$ below datum, Phase Ia.

\section{Achilleion series}

Charcoal samples from Achilleion, on the edge of the Karditsa Plain, near Farsala, Thessaly, Greece (ca $39.3^{\circ} \mathrm{N}, 22.4^{\circ} \mathrm{W}$ ). Samples coll 1973 
and 1974 by M Gimbutas, with D Theocharis, Inspector of Thessalian Antiquities; samples subm by M Gimbutas. Settlement is stratified Neolithic site of Sesklo, Proto-Sesklo, and earliest ceramic period, partially contemporaneous with Anza site in E Macedonia, Yugoslavia. Achilleion habitation periods are divided into 4 main phases, I to IV, from earliest to most recent, with further subdivisions, eg, Ia precedes Ib, IIal precedes IIa2. See Gimbutas (1974) and Ferguson et al (1976) for detailed discussions. Results are given here in order of increasing stratigraphic depth; 1st sample is of questionable phase designation. For calibrated historic ages, see Ferguson et al (1976).

\section{LJ-3203. Achilleion, D-4/19}

$6990 \pm 70$

5040 BC

Charcoal from Sq D, Quad 4, Level 19; from mixed context, possible deep trench. Trench appears to be from at least Phase IVa.

\section{LJ-3202. Achilleion, C-4/9}

$7020 \pm 100$

Charcoal from Sq C, Quad 4, Level 9, depth 149 to $166 \mathrm{~cm}$ below datum, Phase IVa. Other ages: $6930 \pm 155$ for Sq D, Quad 4, Level 2, Phase IVb, UCLA-1882A; $7084 \pm 100$ for Sq D, Quad 2, Level 7, Phase IVa, P-2130.

LJ-2940. Achilleion, B-4/10

$6590 \pm 80$ $4640 \mathrm{BC}$

Charcoal from fire-pit in Sq B, Quad 4, Level 10, depth 215 to $228 \mathrm{~cm}$ below datum, Phase IIIc. Sample from Sq B, Quad 4, Level 13, Phase IIIc: $6964 \pm 87, \mathrm{P}-2125$.

LJ-2943. Achilleion, A-1/10

$6960 \pm 80$

Charcoal from Sq A, Quad 1, Level 10, depth 170 to $183 \mathrm{~cm}$ below datum, Phase IIIc.

\section{LJ-3200. Achilleion, D-2/4}

$\mathbf{7 0 3 0} \pm \mathbf{8 0}$

Charcoal from Sq D, Quad 2, Level II, depth 214 to $224 \mathrm{~cm}$ below datum, Phase IIIc. Ages for Phase IIIb: $7180 \pm 155$ for Sq A, Quad 1, Level 13, UCLA-1896B; $7086 \pm 85$ for Sq A, Quad 2, Level 14, P-2124; $7280 \pm 100$ and $7454 \pm 78$ for Sq A, Quad 3, Level 14, UCLA-1896E and P-2123, respectively.

\section{LJ-2942. Achilleion, A-2, 3/15, 16}

$7200 \pm 50$ $5250 \mathrm{BC}$

Charcoal from Sq A, Quads 2 and 3, Levels 15 and 16, depth 216 to $233 \mathrm{~cm}$ below datum, Phase IIIa2. Other ages for Phase IIIa2: $7107 \pm 86$ for Sq B, Quad 2, Level 16, P-2122; $7181 \pm 86$ for Sq B, Quad 2, Level 17, P-2121. 
LJ-2941. Achilleion, B-4/15, 17, 18

Charcoal from Sq B, Quad 4, Level 15, 17, and 18, depth 272 to $296 \mathrm{~cm}$ below datum; from mixed context of a large rubbish pit, Phase IIIal.

\section{LJ-2944. Achilleion, B-4/18}

$7020 \pm 50$

Charcoal from ash layer at Sq B, Quad 4, Level 18, depth 296 to $300 \mathrm{~cm}$ below datum, Phase IIIal.

\section{LJ-3182. Achilleion, C-1/21}

Charcoal from Sq C, Quad 1, Level 21, depth 258 to 262cm below datum, Phase IIIal.

\section{LJ-3327. Achilleion, A-4/21}

$7120 \pm 60$

Charcoal from Sq A, Quad 4, Level 21, depth 264 to 274cm below datum; from large pit, Phase IIIal. Other age for Phase IIIal: $7342 \pm$ 68 for Sq A, Quad 1, Level 18, P-2120.

\section{LJ-3201. Achilleion, D-2/19}

$7210 \pm 90$

Charcoal from Sq D, Quad 2, Level 19, Phase IIb. Age for Sq D, Quad 2, Level 18, Phase IIb: $7330 \pm 100$, UCLA-1896C.

\section{LJ-3326. Achilleion, A-2/21}

$$
7260 \pm 80
$$

Charcoal from Sq A, Quad 2, Level 22, depth 280 to $292 \mathrm{~cm}$ below datum, Phase IIb.

\section{LJ-3180. Achilleion, D-2/22}

Charcoal from Sq D, Quad 2, Level 22, depth ca $315 \mathrm{~cm}$ below datum. From context of house remains; near sample was a wood beam construction with actual wood still visible. At least 5 parallel beams could be detected; beams were 10 to $15 \mathrm{~cm}$ thick; Phase IIa2.

LJ-3181. Achilleion, D-2/22

$7240 \pm 50$ $\mathbf{5 2 9 0} \mathbf{B C}$

Charcoal from Sq D, Quad 2, Level 22. Same context as LJ-3180, Phase IIa2.

\section{LJ-3328. Achilleion, B-1/19}

$$
7300 \pm 50
$$

Charcoal from Sq B, Quad 1, Level 19, depth ca 295 to $315 \mathrm{~cm}$ below datum, Phase IIa2.

\section{LJ-3325. Achilleion, B-5/20, 21}

Charcoal from Sq B, Area 5, Levels 20 and 21, depth 315 to $325 \mathrm{~cm}$ below datum, Phase IIa2. Age for Phase IIal: $7273 \pm 76$ for Sq A, Quad 1, Level 26, P-2117. 
LJ-3186. Achilleion, B-5/24 datum.

Charcoal from Sq B, Area 5, Level 24, depth ca 340 to $347 \mathrm{~cm}$ below

LJ-3184. Achilleion, B-2/27

$7320 \pm 50$

5370 BC

Charcoal from Sq B, Quad 2, Level 27, depth 361 to $369 \mathrm{~cm}$ below datum, Phase Ib. Age for Sq B, Quad 1, Level 31, Phase Ib: $7260 \pm 155$, UCLA-1882B.

\section{LJ-3329. Achilleion, B-1/26}

$7360 \pm 50$ 5410 BC

Charcoal from Sq B, Quad 1, Level 26, depth 354 to $363 \mathrm{~cm}$ below datum, Phase Ib. Ages for Phase Ia: $7471 \pm 77$ for Sq B, Quad 2, Level 26, P-2118; $7460 \pm 175$ for Sq T, Area 7, Levels 11 and 12, UCLA-1896A. Comment: true historic ages of Anza and Achilleion samples are discussed in detail by Ferguson et al (1976).

\section{LJ-2155. Eiguliai}

$1640 \pm 60$

Charcoal from Eiguliai, habitation Site I-B, near Kaunas, Lithuania (ca $54^{\circ} 54^{\prime} \mathrm{N}, 23^{\circ} 54^{\prime} \mathrm{E}$ ). Corded Pottery site, from end of Chalcolithic to beginning of Bronze age. Excavation 1970 by R Rimantiené; subm by M Gimbutas. Comment (M G): date apparently is for Iron age layer above Corded Pottery site.

\section{LJ-2327. Obre II}

$5960 \pm 140$

4010 BC

Charred grain from Obre II site, on terrace of R Trstionica, tributary of R Bosna, $5 \mathrm{~km}$ from Kakanj and $60 \mathrm{~km} \mathrm{NW}$ of Sarajevo, Bosnia, Yugoslavia (ca $44.2^{\circ} \mathrm{N}, 18.2^{\circ} \mathrm{E}$ ). From Sq V, depth 200 to $220 \mathrm{~cm}$ below surface. Coll 1968 by A Benac and M Gimbutas; subm by M Gimbutas. Most important site of Butmir culture, with 9 habitation horizons and 3 developmental phases established; sample is from classic Bosnian Neolithic period. Obre II dates from UCLA lab: Sq I, depth ca $195 \mathrm{~cm}-4060$ $\pm 60 \mathrm{BC} ; \mathrm{Sq}$ IV, 185 to $200 \mathrm{~cm}-4105 \pm 60 \mathrm{BC} ; \mathrm{Sq} \mathrm{IV}$, ca $260 \mathrm{~cm}-4106$ \pm 60 вс. Dates from E Berlin Lab: Sq I, са 195cm-3790 \pm 80 вс; Sq IV, ca $265 \mathrm{~cm}-3900 \pm 80$ вС (Gimbutas, 1970).

\section{LJ-2407. Vlasac}

$7670 \pm 60$ 5720 вс

Charcoal from Vlasac, Donji Milanovac dist, Iron Gate, Yugoslavia ( $44^{\circ} 32^{\prime}$ N, $2^{\circ} 03^{\prime}$ E). From Sq A/II, Layer XIV. Coll 1971 by D Srejovič and $\mathrm{Z}$ Letica; subm by M Gimbutas. Epipalaeolithic culture, type ProtoLepenski Vir (near Vlasac)-_Schela Cladovei (Rumania).

\section{LJ-2521. Staro Selo-Selevac}

$6080 \pm 70$

Carbonized grain from Staro Selo-Selevac, near Smederevska Palanka, Yugoslavia $\left(44^{\circ} 30^{\prime} \mathrm{N}, 20^{\circ} 53^{\prime} \mathrm{E}\right)$. From Sq VII, Level II. Coll 1968 to 
1970 by R Galovič; subm by M Gimbutas. Sample dates large settlement of classical Vinča culture. Other ages from site are $6113 \pm 80,6152 \pm 80$, and $6366 \pm 100$ (Z-233A, -233B, and -233; R, 1975, v 17, p 149-155).

\section{LJ-2523. Šventoji}

$4640 \pm 60$

Charcoal from Šventoji, Lithuania (ca $56^{\circ} 02^{\prime} \mathrm{N}, 21^{\circ} 05^{\prime} \mathrm{E}$ ). Lower Layer I at site. Excavated by R Rimantiené; subm by M Gimbutas. Šventoji, on Baltic Sea coast N of Palanga, is stratified peat-bog site of about same age as Auvernier and is remarkable for its exceptional preservation of wooden and textile artifacts, from fishing nets and oars to baby cradles and a huge god statue. There are 3 strata: the upper layer is characterized by corded pottery (Schnurkeramik), the lower layer by more primitive pointed based pottery typical of local $\mathrm{E}$ Baltic culture called "Nemunas-Narva culture." Radiocarbon ages from the Vilnius, Lithuania, lab for the upper and lower layers are $4100 \pm 100$ and $4440 \pm 55$, respectively.

\section{LJ-2525. Iwanowice, Poland}

$3840 \pm 60$

Charcoal from Iwanowice, an Early Bronze age settlement site near Krakow, Poland (ca $50^{\circ} \mathrm{N}, 20^{\circ} \mathrm{W}$ ); from Pit 80,90 to $100 \mathrm{~cm}$ deep. Excavated 1969 by J Machnik; subm by M Gimbutas.

\section{LJ-3375. Cyprus}

$2530 \pm 60$ $\mathbf{5 8 0 ~ B C}$

Olive tree wood with copper metal inclusions from Cyprus. Coll 1974 and subm by T Baak, Cyprus Mines Corp, Los Angeles, California. Age indicates possible early date for copper use on Cyprus.

\section{Lefkandi series}

The following samples from the Lefkandi site in Greece were subm by M J Aitken, Oxford Univ Res Lab for Archaeol \& History of Art, Oxford, England. Thermoluminescence dates for potsherds assoc with radiocarbon-dated material provided by $\mathrm{M} \mathrm{J}$ Aitken and J Huxtable.

Excavator was M Popham, who supplied the following information about the site: 3 Early Bronze Age III building phases present at Lefkandi, but pettery changed very little throughout. Duration of period was apparently $<100 \mathrm{yr}$. The 3 building phases are distinguishable. The beginning of Lefkandi Early Bronze Age III occupation presumably occurred at about same time as, or soon after, destruction of the House of Tiles at Lerna, at end of Early Helladic II phase. Previous radiocarbon ages were for beginning of Lerna Early Helladic II at $3870 \pm 60 \mathrm{yr}$ вP, with ages for end of phase at $4070 \pm 70,3980 \pm 70$, and $3930 \pm 60$ : P- 300 , -318, -320 (R, 1962, v 4, p 149-150). Based on Egyptian records of an attack on Egypt, indirectly related to changes in Greece, beginning of Late Helladic IIIC period at Lefkandi is placed at 1200 BC. Allowing time for building and modification of houses at Lefkandi, its destruction can be estimated at ca $1150 \mathrm{BC}$. 


\section{LJ-1832. Lefkandi}

Charcoal from last building phase of Early Bronze III. Coll 1966. See LJ-3046.

\section{LJ-1883. Lefkandi}

$\mathbf{3 0 7 0} \pm \mathbf{8 0}$

Carbonized branch from destruction level belonging fairly early in Late Helladic period. Coll 1965. See LJ-3043.

\section{LJ-2354. Lefkandi}

$3330 \pm 110$

Charcoal from earliest building phase of Early Bronze III. Coll 1969. Possibly contaminated by earlier trial trench of excavator. Thermoluminescence dates for sherds from earliest phase of Early Bronze III are $1535 \mathrm{BC}$ and $1435 \mathrm{BC}$, with average, $1485 \pm 300 \mathrm{BC}$.

\section{LJ-3042. Lefkandi}

$3930 \pm 40$

1980 BC

Charcoal from middle building phase of Early Bronze III. Coll 1969.

\section{LJ-3043. Lefkandi}

$\mathbf{3 0 7 0} \pm 60$

Charcoal. Repeat of LJ-1883.

\section{LJ-3046. Lefkandi}

$1120 \mathrm{BC}$

Charcoal. Repeat of LJ-1832.

$3970 \pm 40$

2020 BC

\section{LJ-3047. Lefkandi}

$4010 \pm 40$

Charcoal from end of Early Bronze III occupation. Coll 1969. Thermoluminescence dates for sherds from late Early Bronze III are $2050 \mathrm{BC}, 2100 \mathrm{BC}$, and $2550 \mathrm{BC}$, with average, $2230 \pm 300 \mathrm{BC}$.

\section{LJ-3048. Lefkandi}

$4690 \pm 90$

Shell assoc with charcoal of LJ-3053. Coll 1969.

\section{LJ-3053. Lefkandi}

$\mathbf{3 7 3 0} \pm \mathbf{5 0}$

$1780 \mathrm{BC}$

Charcoal from Middle Helladic II. Coll 1969. Thermoluminescence dates for sherds from Middle Helladic II are $2800 \mathrm{BC}$ and $2300 \mathrm{BC}$, with average, $2550 \pm 300 \mathrm{BC}$.

General Comment: calibration of results by comparison with the radiocarbon content of wood dated by tree rings measured in this lab (Suess, $m s$ in preparation) shows the following: samples from Late Helladic period: LJ-1883, LJ-3043, came from 12th century BC in agreement with expectations of collector. Samples from Early Bronze Age III, supposedly synchronous with end of Early Helladic II, are considerably older than expected and date from 27 th and 26 th century BC. They are $<100 \mathrm{yr}$ 
younger than wood samples from tomb of Egyptian King Djoser, investigated by many labs, eg, LJ-1314, -1315, UCLA-751.

\section{Bohemia series}

The following 3 samples were subm by E Neustupný, Česklovenská Akad Věd, Archeol Ústav, Prague, Czechoslovakia, and continue a series from R, 1972, v 14, p 369-371. See Neustupný $(1968,1969)$.

\section{LJ-2499. Meclov-Brezí}

Charcoal (Abies, Pinus) from hearth of Hut 3 of Bronze age village. Excavated 1964 by E Čujanová at Meclov-Březí, dist Domažlice, Bohemia. $\mathrm{E} \mathrm{N}$ expected date earlier than $1450 \mathrm{BC}$ - early to middle Bronze age, based on potsherds assoc with same stratum. Comment $(\mathrm{E} \mathrm{N})$ : perhaps site was re-occupied in 5th century AD, during "Dark Ages," by people who "left the fireplaces, some of them inside huts, and a few coarse unornamented sherds that have not been discerned as artifacts from the 'Dark Ages.' ,'

\section{LJ-2501. Meclov-Brezí}

$$
1460 \pm 50
$$

Charcoal (Abies, Pinus) from hearth in Pit 32, ca $25 \mathrm{~m}$ from Hut 3 (see LJ-2499) of Bronze age village. Excavated 1964 by E C̆ujanová at Meclov-Březí, dist Domažlice, Bohemia. Approx same age was expected as predicted for LJ-2499. Comment: same as for LJ-2499.

\section{LJ-2503. Slanska Hora}

$3480 \pm 40$

Charcoal from Pit 3/58 of Early Bronze age village. Excavated 1958 by $\mathrm{V}$ Moucha at Slanska Hora, dist Slany, Bohemia. Late Unetice (Veterov) culture. Assumed historic date was 1550 BC, but was expected by $\mathrm{E} \mathrm{N}$ to be much older. Sample dated previously at $3570 \pm 110 \mathrm{yr}$ BP: LJ-2047, R, 1972, v 14, p 370. LJ-2048 (R, 1972, v 14, p 370-371) from same habitation period dated at $3615 \pm 110 \mathrm{yr}$ BP. These dates for end of Central European Early Bronze age, when calibrated, suggest period ended earlier than formerly believed on archaeol basis.

\section{Georgia, USSR series}

Three samples from Georgian region of USSR subm by M KellyBuccellati, Calif State Univ, Los Angeles, for her study of the Early Trans-Caucasian culture. Archaeol material of Early Trans-Caucasian culture comes mainly from occupational sites, such as Kvatskhelebi (Djavakhishvili and Glonti, 1962). Late manifestations of the culture are linked in Georgia with kurgans from Trialeti and Kurgan I from the Alazani Plain; the latter was constructed as a high mound built in several layers around a burial chamber that contained a funeral cart. See Burney and Lang, 1972. 
LJ-3270. Khramis Didi Gora

Charcoal from Khramis Didi Gora, Bldg Level V, near House 6. Coll 1970 by A J Djavakhishvili and T Kiguradze. Expected date: ca 3000 BC, but calibrated date is from 55 th or 56 th century BC.

\section{LJ-3271. Alazani Valley}

$3800 \pm 60$

Preserved sec of wooden post of kurgan structure from Alazani Valley, Kurgan I. Coll 1974 by S Dedabrishvili and K Pitzkhalauri. Expected date: ca 2000 BC; dates from ca 23rd century BC.

\section{LJ-3272. Kvatskhelebi}

$4190 \pm 60$

Charcoal from Kvatskhelebi, Level C1, House 1. Coll several years ago by A J Djavakhishvili and L Glonti. Site is central to chronology of Kura-Araxes, Early Trans-Caucasian, problem. Expected date: ca 2800 to $2500 \mathrm{BC}$; dates from 29 th or 28 th century $\mathrm{BC}$ and agrees with expectation.

\section{Baja California series}

\section{B. North America}

The following samples were coll 1971 and subm by R A Noble, San Diego Mus of Man and San Diego State Univ, San Diego. Samples were coll on Pacific Coast of Baja California, between Punta Falsa and Punta Negra (ca $\left.29^{\circ} \mathrm{N}\right), 2.4 \mathrm{~km}$ inland, alt $244 \mathrm{~m}$, in cave, shell midden.

\section{LJ-2372. Baja California}

$8890 \pm 60$

Turban shell, from cache of 15 turban shells under rock ledge at depth $208 \mathrm{~cm}$ from datum.

\section{LJ-2375. Baja California}

Charcoal from and around fire hearth, 23 to $31 \mathrm{~cm}$ below surface.

\section{LJ-2377. Baja California}

Modern surface.

Charcoal from level containing human bone, 53 to $61 \mathrm{~cm}$ below

\section{LJ-2379. Baja California}

$$
1790 \pm 80
$$

Charcoal from area of red soil intrusion into midden, also at same level as large basalt block collapsed into cave.

\section{LJ-2381. Baja California} AD 1630

$320 \pm 60$ tion.

Charcoal from near surface. Should give approx date of last occupa- 


\section{San Jose del Valle series}

The following samples were coll 1972 and subm by T J Banks, San Diego Mus of Man and San Diego State Univ, San Diego. Samples were coll at San Diego Mus of Man Site W-246 at San Jose del Valle in Lake Henshaw area of San Diego Co $\left(33^{\circ} 13^{\prime} \mathrm{N}, 116^{\circ} 45^{\prime} \mathrm{W}\right)$.

\section{LJ-2584. San Jose del Valle}

Carbonized string (plant fiber) from Pit $1,30 \mathrm{~cm}$ depth from surface. Assoc with burnt basketry, probably burnt during Diegueño Indian cremation ca 300 yr BP.

\section{LJ-2587. San Jose del Valle}

Charcoal (bark wood) from Pit $1,80 \mathrm{~cm}$ depth from surface.

\section{LJ-2589. San Jose del Valle}

Modern

Charcoal from Pit 10,35cm depth from surface. Assoc with obsidian glass flake, which is being thin-sectioned and hydration-dated at Univ Calif, Los Angeles.

\section{LJ-2590. San Jose del Valle}

$$
320 \pm 90
$$

\section{AD 1630}

Charcoal from Pit 12, $40 \mathrm{~cm}$ depth from surface. Remains of burnt house post; dates period in which posts were used as part of structural elements in house-building in this valley.

\section{LJ-2591. San Jose del Valle}

Modern

Charcoal from Pit $1,100 \mathrm{~cm}$ depth from surface, at base of midden.

\section{Rancho Park North series}

Charcoal and shell samples coll 1974 at Rancho Park N, Great Western Site A, San Diego Co $\left(33^{\circ} 02^{\prime} 30^{\prime \prime} \mathrm{N}, 117^{\circ} 15^{\prime} \mathrm{W}\right)$. Subm by P H Ezell and R L Kaldenberg, San Diego State Univ, Dept Anthropol, San Diego. Listed in order of increasing depth.

\section{LJ-3159. Rancho Park N, 30cm}

$710 \pm 40$

Charcoal manually separated from unsorted ash and sand from Unit $\mathrm{J}-6$, Level $I I I, 30 \mathrm{~cm}$ subsurface, from elementary hearth designated as Feature 7 . Base of hearth was at $30 \mathrm{~cm}$, top of hearth at $26 \mathrm{~cm}$. Coll 1974 by L Carter. Many flakes and tools were around periphery of hearth, with some shells in hearth. No rodent or root activities were found. Represents Kumeyaay intrusion at site.

\section{LJ-3243. Rancho Park N, 30 to $40 \mathrm{~cm}$}

Shells (Chione, Pecten) from Unit J-12, Level IV, 30 to $40 \mathrm{~cm}$ subsurface. Coll 1974 by R L Kaldenberg. Was expected to date La Jollan culture. 
LJ-3244. Rancho Park $N, 40$ to $50 \mathrm{~cm}$

$8020 \pm 80$

Shells (Chione, Pecten) from Unit J-20, Level V, 40 to $50 \mathrm{~cm}$ subsurface. Coll 1974 by R L Kaldenberg. Was expected to date La Jollan complex.

\section{LJ-3245. Rancho Park N, 50 to $60 \mathrm{~cm}$}

$8060 \pm 90$

Shells (Chione, Pecten) from Unit J-20, Level VI, 50 to $60 \mathrm{~cm}$ subsurface. Coll 1974 by R L Kaldenberg. Was expected to reflect transitional La Jollan/San Dieguito techno-complex.

\section{LJ-3160. Rancho Park $N, 70$ to $80 \mathrm{~cm}$}

$\mathbf{8 0 3 0} \pm \mathbf{8 0}$

Shells (Chione, Pecten) from Unit I-15, Level VIII, 70 to $80 \mathrm{~cm}$ subsurface. Sample was near stone pavement, which was probably floor of living structure. Coll 1974 by R L Kaldenberg. Was expected to reflect date of San Dieguito culture.

\section{LJ-3161. Rancho Park N, 100 to $110 \mathrm{~cm}$}

$8280 \pm 80$

Shells (Chione, Pecten) from Unit I-15, Level XI, 100 to $110 \mathrm{~cm}$ subsurface. Coll 1974 by R L Kaldenberg. Reflects date of base of San Dieguito tradition at Great Western Site A. Assoc artifacts include felsite and chalcedony scrapers, obsidian debitage, a bifacial pick, an ovate biface (Kaldenberg and Ezell, 1974).

\section{LJ-3246. Rancho Park N, 110 to $120 \mathrm{~cm}$}

$8120 \pm 80$

Shells (Chione, Pecten) from Unit I-20, Level XII, 110 to $120 \mathrm{~cm}$ subsurface. Coll 1974 by R L Kaldenberg. Was expected to date San Dieguito tradition.

\section{Del Mar series}

Chione shells from Paleo-Indian site, San Diego Mus of Man Sites W-34 and W-34A, on NW point of San Dieguito R inlet, Del Mar, San Diego Co $\left(32.9^{\circ} \mathrm{N}, 117.3^{\circ} \mathrm{W}\right)$. Site at which "Del Mar Man" skull was excavated in 1929. For these shell samples, the upper midden was excav by $\mathrm{R}$ Tyson, the lower midden by $\mathrm{P}$ Helfman; samples were subm by J L Bada, Scripps Inst Oceanog, La Jolla.

\section{LJ-3008. Del Mar}

Surface of lower midden.

LJ-3175. Del Mar

20 to $30 \mathrm{~cm}$ depth in upper midden.

LJ-3176. Del Mar

60 to $70 \mathrm{~cm}$ depth in upper midden.
$8830 \pm 70$

$6880 \mathrm{BC}$

$4500 \pm 60$

2550 BC

$5290 \pm 60$ 3340 BC 
LJ-3177. Del Mar

140 to $150 \mathrm{~cm}$ depth in upper midden.

LJ-3219. Del Mar

100 to $110 \mathrm{~cm}$ depth in lower midden.

\section{LJ-3220. Del Mar}

50 to $60 \mathrm{~cm}$ depth in lower midden.

\section{LJ-3221. Del Mar}

20 to $30 \mathrm{~cm}$ depth in lower midden.

\section{LJ-3262. Del Mar}

70 to $80 \mathrm{~cm}$ depth in lower midden.

LJ-3263. Del Mar

90 to $100 \mathrm{~cm}$ depth in lower midden.

General Comment: amino acid racemization age for "Del Mar Man" bone from lower midden was 48,000 yr (Bada et al, 1974). Also, preliminary racemization ages for shell samples are considerably greater than radiocarbon ages above, suggesting that a major exchange of more modern external carbonate with that originally found in shell has taken place.

\section{LJ-2592. Baja California}

Modern

Charcoal from hearth in dirt cave on SE end of Isla de Cedros, Baja California, Mexico $\left(20^{\circ} 03^{\prime} \mathrm{N}, 115^{\circ} 11^{\prime} \mathrm{W}\right), 15 \mathrm{~cm}$ depth from surface. Coll 1971 and subm by T J Banks. Sample was expected to be more recent than AD 1732, when Cochimi Indian inhabitants of island were all killed by smallpox.

\section{LJ-3173. Las Flores}

$$
2070 \pm 50
$$

Shells (Chione, Pecten) from Las Flores site, San Diego Co $\left(33^{\circ} 17^{\prime}\right.$ $30^{\prime \prime} \mathrm{N}, 117^{\circ} 26^{\prime} 30^{\prime \prime} \mathrm{W}$ ); in alluvium, T10S-R6W-SW $1 / 4$, NE $1 / 4$, Sec 24 , Las Pulgas topo. Assoc with Burial 15. Coll 1973 and subm by P H Ezell. Comment (PHE): sample came from site that cannot be assigned to a position in existing structure of local prehistory. Date was expected to aid in relative positioning of this manifestation.

\section{LJ-3295. Isham Springs}

$1180 \pm 90$ AD 770

Charcoal from Isham Springs, San Diego Co $\left(32^{\circ} 45^{\prime} \mathrm{N}, 117^{\circ} 00^{\prime} \mathrm{W}\right)$; San Diego Mus of Man Site W-172; Unit D-44, 50 to $70 \mathrm{~cm}$ below ground level, within level composed of thermally-fractured rocks and fire-pitted artifacts. Coll and subm 1975 by R L Kaldenberg for Rick Engineering 
Co, San Diego. Site is in Sweetwater area of San Diego Co once famous for its "Elixir" water. A great amount of $\mathrm{CaCO}_{3}$ is found in ground water, removed from charcoal by acidification, and water table is often $<60 \mathrm{~cm}$ below ground surface. Age was expected to reflect inland La Jolla Complex, 3000 to 7000 yr BP. However, an upper level, Kumeyaay, was also found at site, indicating possibility of late prehistoric date, $<$ 1000 yr BP. Date reflects pre-ceramic Yuman occupation at site.

\section{LJ-3296. Cottonwood Creek}

$950 \pm 80$

Charcoal (burned wood) overlying burial site at Cottonwood Creek, San Diego Co $\left(32^{\circ} 50^{\prime} \mathrm{N}, 116^{\circ} 30^{\prime} \mathrm{W}\right)$; from Trench 1, Level VIII, 70 to $80 \mathrm{~cm}$ sub-surface. Coll and subm 1971 by R L Kaldenberg for Rick Engineering Co, San Diego. Comment (RLK): date should reflect preceramic horizon assoc with Mountain aspect of Yuman tradition (PreDiegueño or Kumeyaay). Expected date: 1000 BC to AD 1000. Root hairs were embedded in some of charcoal.

\section{LJ-3395. Camus, Washington}

$2370 \pm 60$

420 вс

Charcoal from Lady I., near Camus, Washington $\left(45.7^{\circ} \mathrm{N}, 122.4^{\circ} \mathrm{W}\right)$, from ca $2 \mathrm{~m}$ below present surface, alt ca $8.7 \mathrm{~m}$. Coll July 1975 and subm by J A Woodward, Mt Hood Comm Coll, Gresham, Oregon. Measured to date earliest Chinookian settlement of lower Columbia R.

\section{LJ-3396. Camus, Washington}

$2320 \pm 50$

Charcoal from same site as LJ-3395; from ca $1 \mathrm{~m}$ below surface, alt $1 \mathrm{~lm}$.

\section{LJ-3398. Camus, Washington}

$2420 \pm 50$

Charcoal; duplicate preparation of same material as LJ-3395.

\section{Mississippi series}

Four samples from Mississippi coast. Subm by E G Otvos, Gulf Coast Research Lab, Ocean Springs, Mississippi. Many more dates for Late Pleistocene and Mid- to Late-Holocene material from marshes, lagoons, and other coastal areas in SE United States were obtained by EGO from Univ Georgia, Louisiana State Univ, and Univ Miami.

\section{LJ-2287. Gulfport}

$3800 \pm 60$

Tree root slices near S bridgehead of Bayou Bernard Bridge (Handsboro Bridge) on Lorraine Rd, Gulfport, local subdivision called Handsboro $\left(30.4^{\circ} \mathrm{N}, 89.1^{\circ} \mathrm{W}\right)$. From 3.7 to $4.6 \mathrm{~m}$ below water level. Obtained from Kraemer Marine Co, from dredging operations in stiff, grayishwhite clay. Tree root slices were thick, fresh material; outer wood was discarded. Coll 1971. Measured to date Pleistocene beach ridge complex along Mississippi coast. Comment (EGO): tree must have grown shortly 
before Mid-Holocene inundation by transgressing sea of Back Bay of Biloxi, and roots extended into well-consolidated Late Pleistocene deposits.

\section{LJ-2294. Gulfport}

Trunks and roots of trees found in standing position in gray, silty clay on S bank of canal near S bridgehead of Harrison Co Industrial Seaway on Lorraine Rd, Gulfport (30.4 $\mathrm{N}$, 89.1 $\left.{ }^{\circ} \mathrm{W}\right)$. Coll 1971. Comment (EGO): trees grew before inundation by Late Pleistocene (Sangamon) interglacial transgression which deposited estuarine silty clay facies of transgressive Biloxi Formation (Otvos, 1972, 1975), which encloses trunks and other woody material.

LJ-2470. Gulfport/Long Beach

Shell fragments from drillhole at corner of Hwy 90 (beach rd) and Lewis Ave, at city limits between Gulfport and Long Beach $\left(30.4^{\circ} \mathrm{N}\right.$, $89.2^{\circ} \mathrm{W}$ ). From Drillhole S-4, $6 \mathrm{~m}$ below sea level, depth interval 1006 to $1062 \mathrm{~cm}$. Comment (EGO): from Late Pleistocene (Sangamon) interglacial, Biloxi Formation (Otvos, 1972, 1975), underlying Sangamon Gulfport Formation.

\section{LJ-2471. Biloxi}

Dark humate material from beach sand from sea level excavation pit at corner of Hwy 90 (beach rd) and Rodenberg Ave, Biloxi $\left(30.4^{\circ} \mathrm{N}\right.$, $88.9^{\circ} \mathrm{W}$ ). Coll 1972 . EGO expected to be very old, perhaps $>42,000 \mathrm{yr}$ BP. Comment (EGO): material impregnated Sangamon Gulfport Formation, beach-dune sand from Late Pleistocene (Otvos, 1972, 1973).

\section{South America}

\section{Lower Chilea quebrada series}

The following 2 charcoal samples from Peru were coll 1970 by $\mathrm{M} \mathrm{H}$ Parsons and C Speth and subm by J R Parsons, Univ Michigan, Mus Anthropol, Ann Arbor, Michigan. Samples are both wood charcoal from midden excavations at Lower Chilca quebrada on central coast of Peru $\left(12^{\circ} 31^{\prime} \mathrm{S}, 77^{\circ} 45^{\prime} \mathrm{W}\right)$. Site is large midden, comprised mainly of valves of sand-dwelling clam (Mesodesma donancium) with lenses of ashy and sandy material, some plant material, and miscellaneous organic material, perhaps partly rodent or reptile feces. Midden appeared undisturbed. Comment (JRP): since ceramics were absent from midden and site was at edge of distinct ancient low wave-cut beach ridge, date of local preceramic period was expected. Ceramics were believed to have 1st appeared on central Peruvian coast at ca 1800 BC.

\section{LJ-3079. Lower Chilca quebrada, 52 to $56 \mathrm{~cm}$}

$$
1670 \pm 50
$$

Wood charcoal from 52 to $56 \mathrm{~cm}$ below ground surface, Level 6 . Within this unit, small, ashy lens occurred in E half of unit and charcoal fragments were more abundant than elsewhere in sec. 


\section{LJ-3080. Lower Chilca quebrada, 95 to $106 \mathrm{~cm}$}

Wood charcoal from 95 to $106 \mathrm{~cm}$ below surface, Level 10 . This was lowest level in which midden debris was abundant; slightly below, sterile beach sand was encountered.

\section{Pachamachay Cave series}

Five samples from Pachamachay Cave in high alt, 4350m, grassland area of central Peru; Junin Prov, Ondores Dist, San Blas Subdist $\left(11^{\circ}\right.$ $06^{\prime} \mathrm{S}, 76^{\circ} 10^{\prime} \mathrm{W}$ ). Coll 1974 by J W Rick; subm by J W Rick, Univ Michigan, Mus Anthropol, Ann Arbor, Michigan. All samples were from same $1 \mathrm{~m}^{2}$ excavation unit at cave mouth, with no intrusive destruction found at site. Material from Preceramic and Formative periods was present. The area had relatively high animal and human populations starting in late Preceramic period. JWR suggests that ceramics might have been expected at an earlier time in highlands than along coast. Site was 2nd largest in region and may have been influenced by either or both of neighboring Chavin and Huanaco cultures. The greatest political, economic, and warring activities of all Peruvian history occurred in Early Formative period. True dates expected by JWR are given below.

\section{LJ-3289. Pachamachay Cave, Level 4}

$$
1850 \pm 50
$$

Wood charcoal from Level 4, ca $40 \mathrm{~cm}$ below surface. Expected from Early Formative period, 900 to 1800 BC.

\section{LJ-3288. Pachamachay Cave, Level 7A}

$1770 \pm 50$

Wood charcoal from Level $7 \mathrm{~A}$, ca $70 \mathrm{~cm}$ below surface. Expected from Early Formative period, 900 to 1800 вС.

\section{LJ-3285. Pachamachay Cave, Level 13}

$2010 \pm 50$

Carbonized camelid dung from hearth at Level 13 , ca $95 \mathrm{~cm}$ below surface. Expected from Early Formative period, 900 to 1800 BC. Comment (JWR): tight clustering of dates for Levels 4, 7A, and 13 indicates intense occupation and pottery production at cave ca $\mathrm{AD}-\mathrm{BC}$ boundary.

\section{LJ-3287. Pachamachay Cave, Feature 6}

$2980 \pm 70$

Grass carbon from Feature 6, between Levels 15 and 16 , ca $130 \mathrm{~cm}$ below surface. Feature 6 was pit filled with bone, charcoal, and loose fill; it was not simple fire-pit, but may have been small house-pit. Sample dates an early phase of San Blas stamped pottery similar to that of Kotosh, but is considerably earlier than inferred age of similar pottery from site. Ceramic/Preceramic transition occurred at Level 17. Expected date: ca 1800 BC. 
LJ-3286. Pachamachay Cave, Level 21

$3660 \pm 60$ $1710 \mathrm{BC}$

Wood charcoal from Level 21 , ca $180 \mathrm{~cm}$ below surface. Date expected was earlier than $1800 \mathrm{BC}$, but result indicates that Preceramic period may have lasted somewhat longer here than in other areas of Peru.

\section{Border Cave series}

$$
\text { D. Africa }
$$

The following samples from Border Cave, Swaziland, were coll 19701972 by $\mathrm{P}$ B Beaumont and subm by J L Bada. Cave underlies crest of steep $\mathrm{W}$ face of Lebombo Range, $>400 \mathrm{~m}$ above Swaziland Lowveld, ca $7 \mathrm{~km}$ N of Ingwavuma R (27० $\left.01^{\prime} 20^{\prime \prime} \mathrm{S}, 31^{\circ} 59^{\prime} 30^{\prime \prime} \mathrm{E}\right)$. Cave cuts directly into cliff face and has roughly semi-circular plan-form, maximum width and depth of ca $40 \mathrm{~m}$ and $30 \mathrm{~m}$, respectively, roof height 2 to $7 \mathrm{~m}$ above present ground surface. Deposits, maximum thickness $4.5 \mathrm{~m}$, contain material from Middle Stone to Iron ages. Cave contained significant quantities of charcoal, well-preserved plant remains, and animal, including human, skeletal material (Cooke et al, 1945; Beaumont and Boshier, 1972; Beaumont, 1973). Bone is being dated by J L Bada by amino acid racemization. Pretoria radiocarbon ages from Beaumont (1973).

\section{LJ-2889. Border Cave}

$480 \pm 70$

Plant material; vegetation from Sq T22, 30 to $38 \mathrm{~cm}$ subsurface, 1st brown sand, upper sublevel. Previous age for vegetation, assoc with Iron age objects, for same level in Sq T19 was $440 \pm 55:$ Pta-715.

\section{LJ-2890. Border Cave}

$580 \pm 70$

Plant material; vegetation from Sq T22, 38 to $46 \mathrm{~cm}$ subsurface, 1st brown sand, upper sublevel. Previously age for vegetation, assoc with few undiagnostic stone artifacts and potsherds that are probably intrusive, for same level in Sq S-19 was $2010 \pm 50$ : Pta-506.

\section{LJ-2891. Border Cave}

$$
640 \pm 70
$$

Plant material; vegetation from $\mathrm{Sq} \mathrm{T} 22,46$ to $53 \mathrm{~cm}$ subsurface, 1st brown sand, upper sublevel. Previous age at same depth in Sq S19 was 13,300 \pm 150: Pta-721.

\section{LJ-2892. Border Cave}

$31,600 \pm 1200$

Charcoal from Sq T22, 69 to $76 \mathrm{~cm}$ subsurface, 1st brown sand, lower sublevel. Charcoal nodules from same level of Sq S2l were dated at 38,600 \pm 1500: Pta-704.

\section{LJ-2982. Border Cave}

$39,500 \pm 2300$

Charcoal from Sq Q23, 2nd brown sand, upper sublevel. 
LJ-3070. Border Cave

$25,750 \mathrm{BC}$ sublevel.

Charcoal from Sq T22, 61 to $69 \mathrm{~cm}$ subsurface, 1st brown sand, upper

LJ-3365. Border Cave

$35,900 \pm 1800$

Charcoal from Sq T23, 2nd brown sand, lower sublevel C.

\section{Mumbwa series}

The following samples are from Mumbwa Caves, Zambia, South Central Africa $\left(14^{\circ} 59^{\prime} \mathrm{S}, 27^{\circ} 05^{\prime} \mathrm{E}\right)$, coll 1973 by D K Savage and subm by J L Bada. Site contains a Middle Stone age-Later Stone age-Iron age sequence of remains. Samples came from excavations within bedrock solution cavities in front of shallow cave in outcrop $S$ of main cave.

\section{LJ-2987. Mumbwa}

$$
-730 \pm 110
$$
datum. Date expected at $<15,000$ yr $\mathrm{BP}$, but apparently included postbomb material. Charcoal from 10 to $40 \mathrm{~cm}$ depth in same sq dated $<150$ yr BP: UCR-272 (R E Taylor, pers commun).

\section{LJ-2988. Mumbwa}

$8680 \pm 70$

Charcoal from single pocket of charcoal in red, gritty soil, $\mathrm{Sq}$ $200 \mathrm{~cm}$ depth from datum. Age expected: 15,000 to 25,000 yr. Age from charcoal at equivalent level of different sq of excavation was $9000 \pm 365$ : UCR-275; level dates late Middle Stone age horizon with some microliths, heavy-duty grinding and bored equipment, and small hand-axe.

\section{LJ-2989. Mumbwa}

$9520 \pm 80$

Charcoal from same location and depth as LJ-2988.

\section{LJ-3031. Mumbwa}

$1070 \pm 50$

Charcoal from same location and depth as LJ-2987. Result indicates charcoal was mixture of post-bomb modern and older materials.

\section{Heuningsneskrans Shelter series}

Samples from rock shelter on farm Heuningsneskrans No. $476,18 \mathrm{~km}$ $\mathrm{N}$ of Ohrigstad, Lydenberg dist, Transvaal, South Africa $\left(24^{\circ} 36^{\prime} \mathrm{S}, 30^{\circ}\right.$ $39^{\prime}$ E). Samples were primarily carbonate of broken ostrich egg shells, with some other shell material included in some samples. Excavated 1968 by $\mathrm{P}$ B Beaumont and subm by J L Bada. Dated both to directly determine ages and to calibrate site for amino acid racemization dating, using aspartic acid; ages given below are from J L Bada (pers commun). Artifacts assoc with early Later Stone age industry. 
LJ-3135. Heuningsneskrans Shelter

$19,320 \pm 240$

Stratum 1c: 290 to $335 \mathrm{~cm}$ depth in Sq A12. Racemization age of assoc bone: 14,300 .

LJ-3136. Heuningsneskrans Shelter

$19,980 \pm 260$

Stratum ld: 328 to $351 \mathrm{~cm}$ depth in Sq A14.

\section{LJ-3137. Heuningsneskrans Shelter}

$17,030 \mathrm{BC}$

Stratum le: 404 to $419 \mathrm{~cm}$ depth in $\mathrm{Sq}$ Al2. Racemization age of assoc bone: ca 22,000. Radiocarbon age of charred bones from hearth from Stratum le, 435 to $442 \mathrm{~cm}$ depth in Sq A12 was 24,630 $\pm 300:$ Pta-101 (R, 1971, v 13, p 385).

\section{LJ-3138. Heuningsneskrans Shelter}

$23,400 \pm 500$

Stratum If: 450 to $488 \mathrm{~cm}$ depth in Sq A12, 450 to $472 \mathrm{~cm}$ depth in Sq A13. Racemization age of assoc bone: 24,800.

\section{LJ-3150. Heuningsneskrans Shelter}

$12,260 \pm 110$

Stratum 1b: 221 to $259 \mathrm{~cm}$ depth in $\mathrm{Sq}$ A14. Racemization age of assoc bone: 10,000. Radiocarbon age of charcoal from Stratum 1b, 221 to $235 \mathrm{~cm}$ depth in Sqs A12 and A13, was 13,100 \pm 110 : Pta-100 (R, 1971, v 13, p 384).

\section{LJ-3198. Heuningsneskrans Shelter}

$9230 \pm 100$

Stratum 2a: 69 to $122 \mathrm{~cm}$ depth in Sq A11. Radiocarbon age of charcoal from Stratum 2a, 76 to $107 \mathrm{~cm}$ depth in Sq A10, was $9780 \pm 85$ : Pta-099 (R, 1971, v 13, p 384).

\section{LJ-3199. Heuningsneskrans Shelter}

$8880 \pm 100$

Stratum 3b: 23 to $53 \mathrm{~cm}$ depth in Sq Al0. Radiocarbon age of charred bones from Stratum $3 \mathrm{~b}, 45$ to $70 \mathrm{~cm}$ depth in $\mathrm{Sq} \mathrm{AB}$, was $7200 \pm 70$ : Pta-112 (R, 1971, v 13, p 384).

\section{LJ-2979. Olduvai Gorge}

$1360 \pm 40$

Land snail shell (Achatina sp) carbonate from Olduvai Gorge, Tanzania; in fluvial silts $2 \mathrm{~m}$ below stratigraphic unit of Namorod Ash, Loc 4D, approx midway between First and Second Faults ( $\left.2^{\circ} 59^{\prime} \mathrm{S}, 35^{\circ} 25^{\prime} \mathrm{E}\right)$. Coll by R L Hay, Univ Calif, Berkeley; subm by J L Bada.

\section{LJ-3330. Olduvai Gorge}

$1360 \pm 70$ AD 590

Amino acids extracted from bone from same location as LJ-2979; from $1.17 \mathrm{~m}$ below Namorod Ash. Coll by R L Hay; subm by J L Bada. 


\section{LJ-3086. Ngorongoro Crater}

Ostrocods from Ngorongoro Volcanic Crater, Tanzania; coll ca 200m $\mathrm{S}$ of $\mathrm{N}$ end of bluffs along $\mathrm{E}$ margin of crater lake in Ngorongoro Crater $\left(3^{\circ} 12^{\prime} \mathrm{S}, 35^{\circ} 33^{\prime} \mathrm{E}\right)$. From layer of ostrocods $5 \mathrm{~cm}$ thick, beneath $2 \mathrm{~m}$ thickness of ostrocodal limestone. Coll by R L Hay; subm by J L Bada.

\section{Bay of Bengal series}

II. GEOLOGIC SAMPLES

The following 5 sediment samples from Bay of Bengal were subm by J R Curray and W Stankus, Scripps Inst Oceanog, La Jolla.

\section{LJ-2363. Bay of Bengal}

$23,200 \pm 1500$

Organic carbon from sediment from Bay of Bengal $\left(14^{\circ} 16^{\prime} \mathrm{N}, 80^{\circ}\right.$ $52^{\prime} \mathrm{E}$ ), water depth $2845 \mathrm{~m}, 160 \mathrm{~cm}$ depth in core.

\section{LJ-2276. Bay of Bengal}

$28,200 \pm 2900$

Organic carbon from sediment from same site as LJ-2363, $500 \mathrm{~cm}$ depth in core.

\section{LJ-2357. Bay of Bengal}

Organic carbon from sediment from Bay of Bengal $\left(15^{\circ} 13^{\prime} \mathrm{N}, 91^{\circ}\right.$ $41^{\prime} \mathrm{E}$ ), water depth $2651 \mathrm{~m}, 100 \mathrm{~cm}$ depth in core.

\section{LJ-2366. Bay of Bengal}

Organic carbon from sediment from same site as LJ-2357, $500 \mathrm{~cm}$ depth in core.

\section{LJ-2278. Bay of Bengal}

Organic carbon from sediment from Bay of Bengal $\left(19^{\circ} 05^{\prime} \mathrm{N}, 87^{\circ}\right.$ $\left.4 \mathrm{I}^{\prime} \mathrm{E}\right)$, water depth $2142 \mathrm{~m}, 500 \mathrm{~cm}$ depth in core.

\section{Pacific series}

The following 6 deep-sea sediment samples were coll 1969 and subm by W H Berger and C G Adelseck, Scripps Inst Oceanog, La Jolla. Sediments were subm as dried material for ${ }^{14} \mathrm{C}$ analysis of carbonate. Measurements made to determine timing of glacial events in deep-sea sediments, done in conjunction with amino acid racemization studies to examine racemization rate and bottom water temperature change.

\section{LJ-3264. Pacific}

Sediment carbonate $\left(2^{\circ} 15^{\prime} \mathrm{N}, 104^{\circ} 10^{\prime} \mathrm{W}\right)$ water depth $3680 \mathrm{~m}, 9$ to $12 \mathrm{~cm}$ depth in core. 
LJ-3265. Pacific

13,060 вС

Sediment carbonate from same site as LJ-3264, 21 to $23 \mathrm{~cm}$ depth in core.

LJ-3266. Pacific

$20,600 \pm 600$

Sediment carbonate from same site as LJ-3264, 36 to $38 \mathrm{~cm}$ depth in core.

\section{LJ-3267. Pacific}

$6670 \pm 140$

Sediment carbonate $\left(1^{\circ} 40^{\prime} \mathrm{N}, 113^{\circ} 50^{\prime} \mathrm{W}\right)$ water depth $3840 \mathrm{~m}, 9$ to $11 \mathrm{~cm}$ depth in core.

\section{LJ-3268. Pacific}

$15,020 \pm 210$

Sediment carbonate from same site as LJ-3267, 24 to $26 \mathrm{~cm}$ depth in core.

LJ-3269. Pacific

$25,800 \pm 700$

Sediment carbonate from same site as LJ-3267, 40 to $42 \mathrm{~cm}$ depth in core.

\section{Lake Ontario series}

The following sediment samples are from a piston core, 70-0-37/E30, from Lake Ontario $\left(43^{\circ} 30.4^{\prime} \mathrm{N}, 76^{\circ} 54.3^{\prime} \mathrm{W}\right)$; water depth, $224 \mathrm{~m}$, total core length, $17 \mathrm{~m}$. Samples were coll 1970 and subm by C F M Lewis, Canadian Dept Energy, Mines, \& Resources, Burlington, Ontario, and J L Bada. Measured to study glacial advance-retreat in Lake Ontario basin (Dreimanis, 1969). Previous date of carbonate fraction of sediment at 1650 to $1660 \mathrm{~cm}$ depth in core, $18,600 \pm 500: \mathrm{LJ}-2323$ (R, 1972, v 14, p 377): glacio-lacustrine sediment at that level was firm, homogeneous, gray, non-calcareous clay with reddish, gray laminae.

\section{LJ-3011. Lake Ontario}

$20,000 \pm 800$

Carbonate fraction of glacio-lacustrine sediment at 1100 to $1110 \mathrm{~cm}$ depth in core. Sediment was firm, homogeneous, gray, non-calcareous clay with rare reddish-gray, calcareous laminae, ca $1 \mathrm{~mm}$ thick.

\section{LJ-3026. Lake Ontario}

$15,300 \pm 600$

Organic fraction of sediment at 1100 to $1110 \mathrm{~cm}$ depth in core, $c f$ LJ-3011.

13,350 вC

\section{LJ-3213. Lake Ontario}

$14,890 \pm 140$

12,940 BC

Carbonate fraction of postglacial lacustrine sediment at 550 to $560 \mathrm{~cm}$ depth in core. Sediment was soft, gray, silty, calcareous clay, laminated with thin, irregular, black sulfide (?) bands ca 1 to $3 \mathrm{~mm}$ thick. 
LJ-3214. Lake Ontario

Carbonate fraction of glacio-lacustrine sediment at 800 to $810 \mathrm{~cm}$ depth in core. Sediment was semi-firm, gray and reddish-gray, calcareous clay with thin laminations ca $2 \mathrm{~mm}$ thick.

\section{LJ-3215. Lake Ontario}

$10,230 \pm 100$

Carbonate fraction of postglacial lacustrine sediment at 350 to $360 \mathrm{~cm}$ depth in core. Same sediment description as for LJ-3213.

\section{LJ-3216. Lake Ontario}

$10,050 \pm 130$

Organic fraction of sediment at 550 to $560 \mathrm{~cm}$ depth in core, of LJ-3213.

\section{BC}

\section{LJ-3217. Lake Ontario}

$14,100 \pm 700$ LJ-3214.

Organic fraction of sediment at 800 to $810 \mathrm{~cm}$ depth in core, $c f$

\section{LJ-3218. Lake Ontario}

$6890 \pm 80$

Organic fraction of sediment at 350 to $360 \mathrm{~cm}$ depth in core, of LJ-3215.

\section{LJ-3107. Lonar Lake}

$28,000 \pm 4000$

Organic carbon from sediment in Lonar Impact Crater, central India, from 48 to $50.5 \mathrm{~m}$ depth. Coll 1974 and subm by K Fredriksson, Div Meteorites, Smithsonian Inst, Washington, D C. Dated to determine minimum age of meteorite impact event. With sample from 67.1 to $67.8 \mathrm{~m}$ depth, it was hoped that erosion/sedimentation rates could be estimated, but other sample contained insufficient organic carbon for analysis.

The following 7 shell samples were coll 1973 and subm by $\mathrm{P} J$ Mudie, Scripps Inst Oceanog, La Jolla. Samples are from San Diego Co. Dated to determine Holocene sedimentation rates.

\section{LJ-2992. Los Penasquitos Lagoon}

$1930 \pm 40$

Shells (Nacoma nausta) from NE sec of Los Penasquitos Lagoon in open plain ca $55 \mathrm{~m}$ from rd $\left(32^{\circ} 55^{\prime} 48^{\prime \prime} \mathrm{N}, 117^{\circ} 14^{\prime} 41^{\prime \prime} \mathrm{W}\right)$, from 190 to $200 \mathrm{~cm}$ depth, in marsh-type sediment.

\section{LJ-2993. Los Penasquitos Lagoon}

$5170 \pm 60$

Shells (Ostrea lurida) from same site as LJ-2992, from 460 to $470 \mathrm{~cm}$ depth. May be from a lagoon mouth. 
LJ-2998. Los Penasquitos Lagoon

Shells (Ostrea lurida) from same site as LJ-2992, from 850 to $860 \mathrm{~cm}$ depth. May be from a beach or channel to a lagoon.

\section{LJ-2994. Sorrento Valley}

$4730 \pm 140$

2780 BC

Shells (Cerithidea californica) from Sorrento Valley, W of Sorrento Valley $\mathrm{Rd}\left(32^{\circ} 55^{\prime} \mathrm{N}, 117^{\circ} 14^{\prime} \mathrm{W}\right)$, from 665 to $685 \mathrm{~cm}$ depth, from grey, clayey sand.

\section{LJ-2995. Sorrento Valley}

$6210 \pm 70$

Shells (Chione fluctafraga) from same site as LJ-2994, from 985 to $1005 \mathrm{~cm}$ depth, from sandy grey mud.

\section{LJ-2996. Los Penasquitos Lagoon}

$3310 \pm 60$

Shells (Ostrea lurida) from E edge of Los Penasquitos Lagoon, where Hwy 101 starts up 1 st hill in Torrey Pines State Park (32 $55^{\prime} 40^{\prime \prime}$ $\mathrm{N}, 117^{\circ} 15^{\prime} 32^{\prime \prime} \mathrm{W}$ ), from 180 to $190 \mathrm{~cm}$ depth, from muddy grey sand.

\section{LJ-2997. Los Penasquitos Lagoon}

$\mathbf{5 4 8 0} \pm \mathbf{7 0}$

Shells (Ostrea lurida) from same site as LJ-2996, from 520 to $540 \mathrm{~cm}$ depth, from shelly sand-rock sediment.

The following 6 peat samples were coll 1974 and subm by P J Mudie.

\section{LJ-3088/LJ-3092。 Elkhorn Slough}

$$
\begin{array}{r}
300 \pm 50 \\
\text { AD } 1650
\end{array}
$$

Compact reddish-brown, fibrous peat from Elkhorn Slough, Monterey Co, California, at Hudson Landing (ca $36^{\circ} 50^{\prime} \mathrm{N}, 121^{\circ} 45^{\prime} \mathrm{W}$ ), $23 \mathrm{~cm}$ below surface of salt marsh. Sample was intended to verify postulated recent changes in geomorphology of Elkhorn Slough. PJM suggested age might be 50 to $100 \mathrm{yr}$ вр.

\section{LJ-3091. Elkhorn Slough}

$990 \pm 50$

Coarse-structured reddish-brown peat from same site as LJ-3088/LJ3092 , from $70 \mathrm{~cm}$ below surface. Same purpose for measurement as for LJ-3088/LJ-3092.

\section{LJ-3096. Elkhorn Slough}

$2460 \pm 50$

Black, gelatinous, finely-divided peat from same site as LJ-3088/ LJ-3092, from $265 \mathrm{~cm}$ below surface. Dated to establish age of fresh water swamp deposits in postulated former delta of San Joaquin R. 


\section{LJ-3097. Drakes Estero}

Red-brown, peaty clay containing some sand, from Drakes Estero, Marin Co, California, from $50 \mathrm{~cm}$ below surface of salt marsh behind Limantour Spit $\left(38^{\circ} 02^{\prime} \mathrm{N}, 122^{\circ} 53^{\prime} \mathrm{W}\right)$. Purpose of dating was to establish age of youngest marsh deposits in this barrier lagoon. PJM suggested sample might be fairly young, 500 to $1000 \mathrm{yr} \mathrm{BP}$.

\section{LJ-3098. Drakes Estero}

$$
470 \pm 50
$$

\section{AD 1480}

Red-brown, peaty clay containing some sand, from same site as LJ3097 , from $54 \mathrm{~cm}$ below surface. Dated to estimate rate of spit growth in lagoon.

\section{LJ-3103. Tijuana Slough}

$1210 \pm 50$

Red-brown, peaty clay containing some sand, from Tijuana Slough, San Diego Co, from $110 \mathrm{~cm}$ below surface of salt marsh behind $\mathrm{N}$ bay mouth bar $\left(32^{\circ} 34^{\prime} \mathrm{N}, 117^{\circ} 08^{\prime} \mathrm{W}\right)$.

\section{LJ-3273. Del Mar Lagoon}

$1430 \pm 40$

Wood fragments in silt and sand from $\mathrm{E}$ arm of Del Mar, San Dieguito, Lagoon, San Diego Co (32 $\left.59^{\prime} \mathrm{N}, 117^{\circ} 17^{\prime} \mathrm{W}\right)$; from depth $47 \mathrm{~cm}$ below sediment surface. Coll 1975 and subm by R Phillips and D Scott, Univ San Diego, Environmental Studies Lab, San Diego. Analyzed to determine sedimentation rates in area and to interpret history of lagoon.

\section{LJ-3347. Del Mar Lagoon}

$$
1180 \pm 50
$$

Wood fragments in silt and sand from same location as LJ-3273; from depth 35 to $37 \mathrm{~cm}$ below sediment surface.

\section{LJ-3351. Mission Bay Marsh}

$$
2360 \pm 60
$$

410 BC

Shells (Chione undatella) from Mission Bay Marsh; in Salicornia Marsh at depth of $312 \mathrm{~cm}$, at $\mathrm{N}$ side of Fiesta Bay in Mission Bay, San Diego $\left(32^{\circ} 48^{\prime} \mathrm{N}, 117^{\circ} 14^{\prime} \mathrm{W}\right)$. Coll June 1975 by $\mathrm{D}$ Scott; subm by R Phillips and D Scott. Dated to study sea level changes and sedimentation rates.

\section{LJ-3366. Nestor Terrace}

Shells (Chione) from Nestor Terrace in Pacific Beach, San Diego, at $+12 \mathrm{~m}$ in sea cliff at $\mathrm{S}$ end of Pacific View Dr $\left(32.8^{\circ} \mathrm{N}, 117.3^{\circ} \mathrm{W}\right)$. Subm by J L Bada. Nestor Terrace was apparently formed by a Late Pleistocene eustatic high sea stand with average rate of uplift of terrace on Pt Loma, San Diego, since formation of terrace of 11 to $14 \mathrm{~cm} / 1000$ $\mathrm{yr}$, assuming ${ }^{230} \mathrm{Th} /{ }^{234} \mathrm{U}$ date of $120,000 \pm 10,000 \mathrm{yr}$ for corals $(\mathrm{Ku}$ and Kern, 1974). Sample was outer $1 / 3$ of shell, ie, 1st fraction to react with $\mathrm{HCl}$ during sample preparation. 


\section{LJ-3373. Nestor Terrace}

Inner $2 / 3$ of shells of LJ-3366.

\section{Panama Coral series}

The following 4 coral samples were coll 1970 and subm by J R Curray and W Stankus. Ages for carbonate fraction of Type 70 coral near Panama must be considered apparent ages only.

\section{LJ-2358. Panama}

$3090 \pm 100$

Coral (9॰36 $\left.36^{\prime \prime} \mathrm{N}, 78^{\circ} 46^{\prime} 55^{\prime \prime} \mathrm{W}\right)$.

\section{$1140 \mathrm{BC}$}

\section{LJ-2359. Panama}

$1730 \pm 40$

Coral $\left(9^{\circ} 35^{\prime} 15^{\prime \prime} \mathrm{N}, 78^{\circ} 40^{\prime} 13^{\prime \prime} \mathrm{W}\right)$.

\section{LJ-2360. Panama}

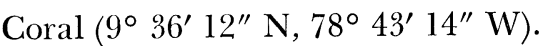

\section{LJ-2361. Panama}

Coral ( $\left.9^{\circ} 36^{\prime} 07^{\prime \prime} \mathrm{N}, 78^{\circ} 44^{\prime} 17^{\prime \prime} \mathrm{W}\right)$.

$440 \mathrm{BC}$

\section{MARINE ORGANISMS}

\section{Marine organisms flesh series}

The following marine organism samples were subm by P M Williams, Scripps Inst Oceanog, La Jolla, for his and the author's use in a study of degree of incorporation of bomb-produced radiocarbon in the marine food chain (Williams \& Linick, 1975; Linick, 1975). Ages are only apparent ages. $\Delta$ values are age-corrected.

$$
\begin{array}{ll} 
& -\mathbf{6 0} \pm \mathbf{4 0} \\
\text { LJ-3027. Squid } & \begin{array}{r}
\Delta=\mathbf{5} \% \\
\delta^{13} C=-17.6 \%
\end{array}
\end{array}
$$

Squid ( $\left.3^{\circ} 0 \mathrm{I}^{\prime} \mathrm{N}, 149^{\circ} 59^{\prime} \mathrm{W}\right)$; coll April 1971 near sea surface by J Wells. Muscle from center sec of body was used. Squid are known to feed on both surface and deeper organisms.

\section{LJ-3030. Squid}

Sample of same squid muscle as LJ-3027.

\section{LJ-3054. Myctophids}

$$
\begin{array}{r}
-160 \pm 40 \\
\Delta=+18 \pm \mathbf{5} \% \\
\delta^{13} C=-17.6 \%
\end{array}
$$

$$
\begin{array}{r}
-\mathbf{1 2 7 0} \pm \mathbf{5 0} \\
\Delta=+\mathbf{1 6 8} \pm \mathbf{7} \% \\
\delta^{13} C=-18.2 \%
\end{array}
$$

Whole bodies of several myctophids $\left(28^{\circ} 31^{\prime} \mathrm{N}, 155^{\circ} 53^{\prime} \mathrm{W}\right)$; coll May 1974 in a surface tow of $505 \mu \mathrm{m}$-mesh neuston net by M M Mullin. 


\section{LJ-3058. Mahi-mahi}

$$
\begin{array}{r}
-\mathbf{1 0 1 0} \pm \mathbf{5 0} \\
\Delta=+\mathbf{1 3 1} \pm \mathbf{7} \% \\
\delta^{13} \mathrm{C}=-14.2 \%
\end{array}
$$

Mahi-mahi or dolphin (Corythaena sp) $\left(28^{\circ} 00^{\prime} \mathrm{N}, 155^{\circ} 23^{\prime} \mathrm{W}\right)$; coll Aug 1973 near sea surface by P M Williams.

\section{LJ-3069. Squid}

$$
\begin{array}{r}
-930 \pm \mathbf{5 0} \\
\Delta=+\mathbf{1 2 0} \pm \mathbf{7} \% \\
\delta^{13} C=-17.9 \%
\end{array}
$$

Squid (Symplechtouthis onaliensis) $\left(30^{\circ} 58^{\prime} \mathrm{N}\right.$, ca $\left.155^{\circ} \mathrm{W}\right)$; coll June 1972 near sea surface by V Mead. Muscle from center sec of body was used.

\section{LJ-3073. Pleuragramma antarcticum

$$
\begin{array}{r}
920 \pm 40 \\
\Delta=-111 \pm 4 \% 0 \\
\delta^{13} C=-32.1 \%
\end{array}
$$

Whole body material of Pleuragramma antarcticum $\left(77^{\circ} 11^{\prime} \mathrm{S}, 172^{\circ}\right.$ $06^{\prime}$ E); coll Feb 1972 at 0 to $200 \mathrm{~m}$ depth. Stomach contents were almost entirely krill (Euphausia crystallorophias); krill samples obtained at same time and location were ${ }^{14} \mathrm{C}$-analyzed by $\mathrm{M}$ Rubin, US Geol Survey, Washington, DC; result: $\delta^{14} \mathrm{C}=-107 \pm 20 \%$.

\section{LJ-3074. Dissostichus mawsoni}

$$
\begin{array}{r}
1060 \pm 40 \\
\Delta=-127 \pm 4 \% \\
\delta^{13} C=-32.1 \%
\end{array}
$$

Muscle of Dissostichus mawsoni (ca $77^{\circ} 45^{\prime} \mathrm{S}, 166^{\circ} 30^{\prime} \mathrm{E}$ ); coll Nov 1973 at ca $500 \mathrm{~m}$ depth. This fish, ranging up to $2 \mathrm{~m}$ long, was caught near bottom of McMurdo Sound; it feeds almost entirely on $P$ antarcticum (see LJ-3073). PMW considers lower ${ }^{14} \mathrm{C}$ content of $\mathrm{LJ}-3074$ relative to that of LJ-3073 to be a result of analyzing only the lipid-rich muscle of the former, compared to whole body of the latter. $\Delta$ of dissolved inorganic carbon of surface waters immediately $\mathrm{N}$ of the Ross Sea, at that time, was quite similar to $\Delta$ of these Antarctic fish.

\section{California coast shell series}

Living specimens of mollusk (Mytilus californianus) coll July 1975 by $\mathrm{R} T$ Sullins, III, Univ California, San Diego, from 5 sites along California coast; shells were subm by RTS for analysis of carbonate as a geochemical study. Variation of radiocarbon concentrations of these post-bomb shells results from both a lat variation of Pacific surface water dissolved carbonate $\Delta$, caused by large-scale oceanic currents and vertical mixing processes, and from localized oceanographic conditions; degree of upward mixing of water of relatively low $\Delta$, here considerably controlled by the California Current, strongly influences $\Delta$ of surface seawater, and, in turn, the shells growing in it (Berger et al, 1966; Taylor \& Berger, 1967; Linick, 1975). $\Delta$ values are age-corrected from 1975 to 1950 . Ages are, of course, apparent ages. 
LJ-3390. San Diego

$$
-910 \pm 60
$$

Shells from San Diego, ca $200 \mathrm{~m} \mathrm{~S}$ of Ocean Beach pier $\left(32^{\circ} 44^{\prime} \mathrm{N}\right.$, $\left.118^{\circ} 15^{\prime} \mathrm{W}\right)$.

\section{LJ-3391. Ventura}

$$
\Delta=\begin{array}{r}
-760 \pm 50 \\
+96 \pm \mathbf{5} \% o
\end{array}
$$

Shells from Ventura State Beach, ca $2 \mathrm{~km} \mathrm{~N}$, along coast, of Ventura $\left(34^{\circ} 20^{\prime} \mathrm{N}, 119^{\circ} 22^{\prime} \mathrm{W}\right)$.

\section{LJ-3392. San Simeon}

$$
-560 \pm 40
$$

Shells from San Simeon State Beach, ca $1.6 \mathrm{~km} \mathrm{~N}$ of San Simeon $\left(35^{\circ} 38^{\prime} \mathrm{N}, 121^{\circ} 14^{\prime} \mathrm{W}\right)$.

\section{LJ-3393. Bean Hallow}

$$
-\mathbf{5 0 0} \pm \mathbf{5 0}
$$

Shells from Bean Hallow State Beach $\left(37^{\circ} 16^{\prime} \mathrm{N}, 122^{\circ} 25^{\prime} \mathrm{W}\right)$.

\section{LJ-3394. Trinidad Bay}

$$
-340 \pm 40
$$

next to town of Trinidad, ca $40 \mathrm{~km} \mathrm{~N}$ of Eureka $\left(41^{\circ} 04^{\prime} \mathrm{N}, 124^{\circ} 07^{\prime} \mathrm{W}\right)$.

\section{LJ-3425. Trinidad Bay}

$\Delta=+40 \pm 6 \%$

Repeat of shells from same location as LJ-3394.

$$
\begin{array}{r}
-\mathbf{3 1 0} \pm \mathbf{5 0} \\
\Delta=+\mathbf{3 7} \pm \mathbf{6} \% \text { o }
\end{array}
$$

\section{REFFRENCES}

Bada, J L, Schroeder, R A, and Carter, G F, 1974, New evidence for the antiquity of man in North America deduced from aspartic acid racemization: Science, $v 184$ p 791-793.

Beaumont, P B, 1973, Border Cave-a progress report: S African Jour Sci, v 69, p 41-46. Beaumont, P B and Boshier, A K, 1972, Some comments on recent findings at Border Cave, northern Natal: S African Jour Sci, v 68, p 22-24.

Berger, R, Taylor, R E, and Libby, W F, 1966, Radiocarbon content of marine shells from the California and Mexican west coast: Science, v 153, p 864-866.

Bien, G S and Pandolfi, L J, 1972, La Jolla natural radiocarbon measurements VI: Radiocarbon, v 14, p 368-379.

Broecker, W S and Olson, E A, 1959, Lamont radiocarbon measurements VI: Radiocarbon, v 1, p 111-132.

Burney, C and Lang, D M, 1972, The Peoples of the Hills: New York, Praeger Publishers.

Cain, W F and Suess, H E, 1976, Carbon 14 in tree rings: Jour Geophys Research, v $81, \mathrm{p} 3688-3694$.

Cooke, H B S, Malan, B D, and Wells, L H, 1945, Fossil man in the Lebombo Mountains, South Africa: the 'Border Cave', Ingwavuma district, Zululand: Man, v 3, p 6-13.

Djavakhishvili, A J and Glonti, L, 1962, Urbnisi I: archeological excavations carried out in 1954-1961 at the site of Kvatskhelebi, Tbilisi, (in Georgian with Russian summary.)

Dreimanis, A, 1969, Late Pleistocenc Lakes in the Ontario and the Erie Basins: 12th conf Great Iakes Research Proc, Internatl Assoc Great Lakes Research, p 170-180.

Ferguson, C W, 1968, Bristlecone pine: science and esthetics: Science, v 159, p 839-846.

Ferguson, C W, Gimbutas, M, and Suess, H E, 1976, Historical dates for neolithic sites of southeast Europe: Science, v 191, p 1170-1172. 
Gimbutas, M, 1970, Obre, Yugoslavia_two neolithic sites: Archaeology, v 23, p 287-297. 1972, Excavation at Anza, Macedonia: Archaeology, v 25, p 112-123.

1974, The gods and goddesses of old Europe: 7000 to 3500 BC: myths, legends, and cult images: Berkeley and Los Angeles, Univ California Press, $303 \mathrm{p}$

Kaldenberg, R L and Ezell, P H, 1974, Results of the archaeological mitigation of Great Western Sites A and C, located on the proposed Rancho Park North development near Olivenhain, California: Environmental Impact rept subm to County of San Diego.

Ku, T-L and Kern, J P, 1974, Uranium-series age of the Upper Pleistocene Nestor Terrace, San Diego, California: Geol Soc America Bull, v 85, p 1713-1716.

Linick, T W, 1975, Uptake of bomb-produced carbon-14 by the Pacific Ocean: PhD dissert, Univ California, San Diego.

Linick, T W and Suess, H E, 1972, Bomb-produced radiocarbon in the surface water of the Pacific Ocean, in: 8th internatl conf on radiocarbon dating Proc, Wellington, New Zealand (Royal Soc New Zealand), v 1, p C-87-C-93.

Neustupný, E, 1968, Absolute chronology of the neolithic and aeneolithic periods in Central and Southeastern Europe: Slovenska Archaeol, v XVI-1, p 19-56. 1969, Absolute chronology of the neolithic and aeneolithic periods in Central and South-East Europe II: Archeol rozhledy, v XXI-6, p 783-810.

Otvos, E G, Jr, 1972, Mississippi Gulf Coast Pleistocene beach barriers and the age problem of the Atlantic-Gulf Coast "Pamlico"-"Ingleside" beach ridge system: Southeastern Geol, v 14, p 241-250.

1973, Geology of the Mississippi-Alabama coastal area and nearshore zone: Guidebook, New Orleans Geol Soc, 67 p.

1975, Late Pleistocene transgressive unit (Biloxi formation), northern Gulf Coast: Amer Assoc Petr Geologists Bull, v 59, p 148-154.

Ralph, E K and Stuckenrath, R, Jr, 1962, University of Pennsylvania radiocarbon dates V: Radiocarbon, v 4, p 144-159.

Rafter, T A, 1955, $\mathrm{C}^{14}$ variations in nature and the effect on radiocarbon dating: New Zealand Jour Sci Tech B, v 37, p 20.

Srdoč, D, Sliepčevic, A, and Planinic, J, 1975, Rudjer Bošković Institute radiocarbon measurements III: Radiocarbon, v 17, p 149-155.

Suess, H E, 1954, Natural radiocarbon measurements by acetylene counting: Science, v $120, \mathrm{p} 5$.

1967, Bristlecone pine calibration of the radiocarbon time scale, in: Monaco symposium on radioactive dating Proc, March 2-10, 1967, IAEA, Vienna, p 143-151.

Taylor, R E and Berger, R, 1967, Radiocarbon content of marine shells from the Pacific coasts of Central and South America: Science, v 158, p 1180-1182.

Vogel, J C and Marais, M, 1971, Pretoria radiocarbon dates I: Radiocarbon, v 13, p 378-394.

Williams, P M and Linick, T W, 1975, Cycling of organic carbon in the ocean: use of naturally occurring radiocarbon as a long and short term tracer, in: Isotope ratios as pollutant source and behaviour indicators, IAEA, Vienna, p 153-167. 